\title{
METABOLISM OF $\left[1-{ }^{14} \mathrm{C}\right]$ SODIUM LACTATE AND $\left[2-{ }^{14} \mathrm{C}\right]$ SODIUM LACTATE BY RAM SPERMATOZOA
}

\author{
T. O'SHEA AND R. G. WALES \\ Department of Veterinary Physiology, University of Sydney, Sydney, Australia
}

(Received 25th February 1967, revised 6th May 1967)

\begin{abstract}
Summary. The metabolism of specifically labelled lactate by ram spermatozoa was studied under various experimental conditions. Increasing the rate at which diluted ram semen was cooled to $5^{\circ} \mathrm{G}$ caused a greater decrease in the formation of labelled carbon dioxide from $\left[2-{ }^{14} \mathrm{C}\right]$ lactate than from $\left[1-{ }^{14} \mathrm{C}\right]$ lactate. Changes in the amount of lactate present did not affect the relative amounts of carbon dioxide formed from carbon atoms one and two of lactate.

Washing ram spermatozoa, that had been recently ejaculated, decreased the amount of labelled carbon dioxide formed from $\left[2-{ }^{14} \mathrm{C}\right]$ lactate relative to that formed from $\left[1-{ }^{14} \mathrm{C}\right]$ lactate, whereas the reverse effect occurred on washing spermatozoa that had been stored in test tubes at $37^{\circ} \mathrm{C}$ for $3 \mathrm{hr}$.

When washed ram spermatozoa were incubated with lactate as substrate, labelled acetic acid accumulated from $\left[2-{ }^{14} \mathrm{C}\right]$ lactate but not from $\left[1-{ }^{14} \mathrm{C}\right]$ lactate, both in the absence and in the presence of added potassium chloride $(1 \mathrm{~mm})$ and magnesium chloride $(2 \mathrm{~mm})$.
\end{abstract}

\section{INTRODUCTION}

Ram spermatozoa form more carbon dioxide from carbon-one than from carbontwo of lactate and this difference has been found to increase on cooling and on storage at $5^{\circ} \mathrm{C}$ (O'Shea \& Wales, 1967). Thus part of the lactate forming acetyl CoA does not undergo complete oxidation in the citric acid cycle and some product other than carbon dioxide must accumulate.

In the present paper, the effects of a number of changes in environmental conditions on the relative amounts of carbon dioxide from carbons one and two of lactate are investigated. As potassium and magnesium are important in the metabolism of ram spermatozoa, whether recently collected or stored (Lardy \& Phillips, 1943; Blackshaw, 1953; White, 1953a, b; Dott \& White, 1964; Wallace \& Wales, 1964; Wales \& O'Shea, 1966; O'Shea \& Wales, 1967), particular attention is paid to the effect of these ions on the ratio of carbon dioxide formed from carbons- 1 and 2 of lactate during metabolism. The accumulation of carboxylic acids from specifically labelled lactate is also examined. 


\section{General}

\section{MATERIALS AND METHODS}

Semen, diluents, incubation in Warburg flasks, analytical techniques and statistical methods have been described (O'Shea \& Wales, 1966). The percentage of spermatozoa unstained was estimated using congo red nigrosin (Blackshaw, 1958) and motility was given a score between 4 and 0 (Emmens, 1947). Data expressed as percentages were converted to angles before statistical analysis was performed.

In Experiment 1, normal cooling to $5^{\circ} \mathrm{C}$ took 2 to $3 \mathrm{hr}$ and was carried out by surrounding the test tubes containing diluted semen with a water jacket before cooling was begun (O'Shea \& Wales, 1964). Fast cooling was carried out by placing the test tubes in a cold room without a water jacket, and spermatozoa were cold-shocked by plunging the test tubes into water at $5^{\circ} \mathrm{C}$.

\section{Isolation of organic acids}

The technique of partition chromatography on silicic acid was adapted for the collection of radio-active eluents and their direct assay by liquid scintillation techniques.

For the column $6 \mathrm{~g}$ of silicic acid (100 Mesh, Mallinckrodt Chemical Works) was triturated with $4 \mathrm{ml}$ of $0.5 \mathrm{~N} \mathrm{H}_{2} \mathrm{SO}_{4}$, made into a slurry with acidified hexane $\left(0.5 \mathrm{~N} \mathrm{H}_{2} \mathrm{SO}_{4}\right)$ and transferred to a glass chromatographic tube of

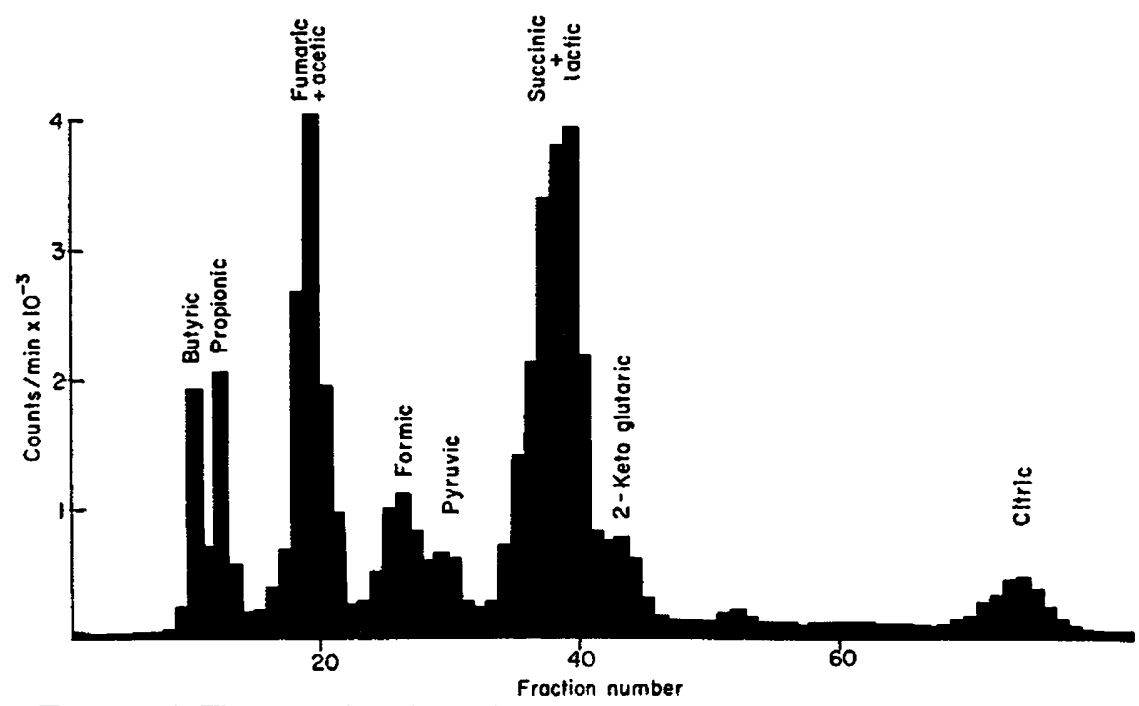

TExT-FIG. 1. The separation of organic acids by partition chromatography on silicic acid with elution by hexane: butanol.

$10 \mathrm{~mm}$ internal diameter and $30 \mathrm{~cm}$ long. The sample to be analysed (approximately $0.2 \mathrm{ml}$ ) was acidified with $5 \mathrm{~N} \mathrm{H}_{2} \mathrm{SO}_{4}$, triturated with $0.5 \mathrm{~g}$ silicic acid and transferred into the top of a prepared column.

Hexane:butanol solvents (Neish, 1949) were used and a mixing device was employed to increase progressively the concentration of butanol in the hexane applied to the column (see Donaldson, Tulane \& Marshall, 1952). The lower reservoir, with a volume of $150 \mathrm{ml}$, contained hexane equilibrated with 
$0.5 \mathrm{~N} \mathrm{H}_{2} \mathrm{SO}_{4}$ and a magnetic stirrer. The solvent blending was accomplished by delivering $100 \mathrm{ml}$ acidified hexane:butanol $(1: 1)$ followed by $100 \mathrm{ml}$ acidified hexane: butanol $(1: 3)$, about $3 \mathrm{~cm}$ below the surface of the hexane. Where necessary, after $200 \mathrm{ml}$ of eluent had been collected, the resultant mixture in the lower reservoir was added directly to the liquid above the column. For scintillation counting the fractions $(3.4 \mathrm{ml})$ were added to $6 \mathrm{ml}$ of xylene containing $0.4 \%(\mathrm{w} / \mathrm{v})$ 2,5-diphenyl-oxazole (PPo) and 0.01\% 1,4-bis-2-(4methyl-5-phenyloxazolyl)-benzene (Dimethyl POPOP), obtained from the Packard Instrument Company.

Radio-active peaks were recovered and re-chromatographed in the presence of known labelled compounds using a constant solvent system (Bulen, Varner \& Burrell, 1952). The substance responsible for the radio-active peak tentatively identified as acetate, was volatile on steam distillation (95\% recovery) and ran with acetate when re-chromatographed with the addition of authentic labelled acetate or formate using hexane:n-butanol $(93: 7)$. The acetate peak was not observed if aliquots were acidified before drying at room temperature.

Using the system described, isotopically labelled acids, singly, in pairs and in mixtures, were placed in columns to determine the order in which they were eluted (Text-fig. 1).

\section{RESULTS}

Aliquots of ram semen, diluted with 9 volumes of a diluent containing fructose $(4 \mathrm{~mm})$ and casein $(4 \mathrm{~g} / 100 \mathrm{ml} \mathrm{w} / \mathrm{v})$ were cooled to $5^{\circ} \mathrm{C}$ at three different rates and re-warmed to $37^{\circ} \mathrm{C}$ about $4 \mathrm{hr}$ after semen collection. The percentage of spermatozoa unstained and their respiration were compared with those of control aliquots, stained or incubated shortly after collection. To obtain a similar concentration of fructose in the suspension cooled to $5^{\circ} \mathrm{C}$ as in the controls, more fructose ( $3 \mu \mathrm{mole} /$ flask) was added before incubation of the treated aliquots $(0.8 \mathrm{ml})$ in small Warburg flasks. Mean results (Table 1) for four ejaculates $\left(1.8\right.$ to $3.1 \times 10^{8}$ cells/flask $)$ show a decrease in the ${ }^{14} \mathrm{CO}_{2}$ ratio $(P<0.05)$ and in the percentage of spermatozoa unstained $(P<0.01)$ with increasing rate of cooling. The decrease in oxygen uptake with increasing rate of cooling became less as the cooling rate increased $(P<0.05)$.

TABLE 1

EFFECT OF RATE OF COOLING TO $5^{\circ} \mathrm{C}$ ON RAM SPERMATOZOA

\begin{tabular}{l|c|c|c}
\hline \multicolumn{1}{c|}{ Treatment } & $\begin{array}{c}\text { Oxygen } \\
\text { uptake } \\
\left(\mu \text { mole } 10^{8} \text { sperm.) }\right.\end{array}$ & ${ }^{14} \mathrm{CO}_{2}$ ratio & $\begin{array}{c}\text { Spermatozoa } \\
\text { unstained } \\
(\%)\end{array}$ \\
\hline Control & 3.35 & 94.4 & 93 \\
Normal cooling & 1.98 & 77.6 & 71 \\
Fast cooling & 1.21 & 64.6 & 60 \\
Cold shock & 0.87 & 58.8 & 37 \\
S.E.M. (d.f.) & $0.28(9)$ & $6.96(9)$ & $2.5(9)$ \\
\hline
\end{tabular}

Values are the means for four ejaculates. The ${ }^{14} \mathrm{CO}_{2}$ ratio is the ${ }^{14} \mathrm{CO}_{2}$ formed from $[2-14 \mathrm{C}]$ lactate expressed as a percentage of the ${ }^{14} \mathrm{CO}_{2}$ formed from $\left[1-{ }^{14} \mathrm{C}\right]$ lactate. 
TABLe 2

EFFEGT OF $\mathrm{pH}$ ON WASHED RAM SPERMATOZOA WITH LAGTATE AS SOLE SUBSTRATE

\begin{tabular}{|c|c|c|c|c|c|}
\hline \multirow{2}{*}{$p H$} & \multirow{2}{*}{$\begin{array}{l}\text { Oxygen } \\
\text { uptake }\end{array}$} & $\mathrm{CO}_{2}$ formec & rrbon atom & \multirow{2}{*}{${ }^{14} \mathrm{CO}_{2}$} & \multirow{2}{*}{ Motility } \\
\hline & & \multicolumn{2}{|c|}{$\left[1-{ }^{14} \mathrm{C}\right]$ lactate $\left[2{ }^{14} \mathrm{C}\right]$ lactate } & & \\
\hline $\begin{array}{l}6 \cdot 1 \\
6 \cdot 9 \\
7 \cdot 6\end{array}$ & $\begin{array}{l}1 \cdot 78 \\
2 \cdot 55 \\
2 \cdot 81\end{array}$ & $\begin{array}{l}0.69 \\
0.84 \\
0.80\end{array}$ & $\begin{array}{l}0.53 \\
0.76 \\
0.73\end{array}$ & $\begin{array}{l}76 \\
90 \\
92\end{array}$ & $\begin{array}{l}2 \cdot 7 \\
2 \cdot 8 \\
1.8\end{array}$ \\
\hline $\begin{array}{l}\text { S.E.M. } \\
\text { (d.f.) }\end{array}$ & $0 \cdot 12(6)$ & \multicolumn{2}{|c|}{$0.07(6)$} & $3.37(6)$ & $0.14(12)$ \\
\hline
\end{tabular}

Values are the means for four ejaculates and the metabolic data are expressed as $\mu$ mole $/ 10^{8}$ spermatozoa over the experimental period $(3 \mathrm{hr})$. The ${ }^{14} \mathrm{CO}_{2}$ ratio is the ${ }^{14} \mathrm{CO}_{2}$ formed from $\left[2-{ }^{14} \mathrm{C}\right]$ lactate expressed as a percentage of the ${ }^{14} \mathrm{CO}_{2}$ formed from $\left[1-{ }^{14} \mathrm{C}\right]$ lactate.

In the next experiment spermatozoa were washed and incubated in diluents containing sodium lactate $(12 \mathrm{~mm})$, potassium chloride $(1 \mathrm{~mm})$, magnesium chloride (2 $\mathrm{mm}$ ) and $20 \mathrm{~mm}$ mono- and di-sodium phosphate buffer at three $\mathrm{pH}$ values $(6,7$ or 8$)$. After the addition of 1 volume of semen to 9 volumes of each diluent the mean $\mathrm{pH}$ in the three suspensions was $6 \cdot 1,6.9$ and 7.6. Aliquots $(0.9 \mathrm{ml})$ of four ejaculates ( 1.4 to $4.3 \times 10^{8}$ cells/flask) were incubated in Warburg flasks $(5 \mathrm{ml})$ and the results are presented in Table 2. There was a decreased oxygen uptake at $\mathrm{pH} 6.1 \quad(P<0.01)$ and lowered motility at $\mathrm{pH} 7.6$ $(P<0 \cdot 01)$. However (due to variation between ejaculates), there was no significant effect of $\mathrm{pH}$ on the production of carbon dioxide. Overall, there was more carbon dioxide formed from carbon atom one than from carbon atom two of lactate $(P<0.01)$.

The metabolism of aliquots of semen diluted with 6 volumes of a potassiumand magnesium-free diluent containing fructose $(6 \mathrm{~mm})$ and stored in test tubes

\section{TABLE 3}

EFFECT OF WASHING AND OF STORAGE AT $37^{\circ} \mathrm{C}$ ( 3 HR) ON THE OXIDATIVE METABOLISM OF RAM SPERMATOZOA INCUBATED WITH FRUCTOSE ( 6 $\mu$ MOLE/FLASK) AND LACTATE

\begin{tabular}{|c|c|c|c|c|}
\hline Treatment & Washing & 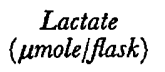 & $\begin{array}{c}\text { Oxygen uptake } \\
\left(\text { umole } / 10^{8} \text { cells }\right)\end{array}$ & ${ }^{14} \mathrm{CO}_{2}$ ratio \\
\hline Control & $\begin{array}{l}- \\
+\end{array}$ & $\begin{array}{r}4 \\
12 \\
4 \\
12\end{array}$ & $\begin{array}{l}1.82 \\
1.76 \\
1.74 \\
1.67\end{array}$ & $\begin{array}{l}77 \cdot 4 \\
85 \cdot 4 \\
69 \cdot 6 \\
65 \cdot 9\end{array}$ \\
\hline Stored at $37^{\circ} \mathrm{C}$ & $\begin{array}{l}- \\
+\end{array}$ & $\begin{array}{r}4 \\
12 \\
4 \\
12\end{array}$ & $\begin{array}{l}0.65 \\
0.68 \\
0.70 \\
0.74\end{array}$ & $\begin{array}{l}35 \cdot 8 \\
35 \cdot 3 \\
43 \cdot 5 \\
46 \cdot 7\end{array}$ \\
\hline S.E.M. (d.f.) & & & $0.018(14)$ & $3 \cdot 17(14)$ \\
\hline
\end{tabular}

Values are the means for three ejaculates. The ${ }^{14} \mathrm{CO}_{2}$ ratio is the ${ }^{14} \mathrm{CO}_{2}$ formed from $\left[2-{ }^{4} \mathrm{C}\right]$ lactate expressed as a percentage of the ${ }^{14} \mathrm{CO}_{2}$ formed from $\left[1-{ }^{14} \mathrm{C}\right]-$ lactate. 
at $37^{\circ} \mathrm{C}$ for $3 \mathrm{hr}$, was compared with that of aliquots incubated shortly after collection. To help determine whether any effects of storage were due to changes in the cells themselves or to changes in the composition of the seminal plasma, aliquots washed immediately before incubation were compared with unwashed aliquots. Aliquots of diluted semen $(0.9 \mathrm{ml})$ were incubated in Warburg flasks

TABLE 4

OXIDATION OF LACTATE AND ACETATE BY WASHED RAM SPERMATOZOA WITH AND WITHOUT THE ADDITION OF $\mathrm{K}^{+}(1 \mathrm{mM})$ AND $\mathrm{Mg}^{2+}(2 \mathrm{mM})$

\begin{tabular}{|c|c|c|c|c|c|c|c|c|}
\hline \multicolumn{2}{|c|}{$\begin{array}{c}\text { Substrate } \\
(\mu \text { molelflask })\end{array}$} & \multirow{2}{*}{$K^{+}+M g^{2+}$} & \multirow{2}{*}{$\begin{array}{l}\text { Position of } \\
{ }^{14} \text { C label }\end{array}$} & \multirow{2}{*}{$\begin{array}{l}\text { Oxygen } \\
\text { uptake }\end{array}$} & \multicolumn{2}{|c|}{$\begin{array}{c}\mathrm{CO}_{2} \text { formed from } \\
\text { carbon position labelled }\end{array}$} & \multicolumn{2}{|c|}{${ }^{14} \mathrm{CO}_{2}$ ratios. } \\
\hline Lactate & Acetate & & & & Lactate & Acetate & Lactate & Acetate \\
\hline 30 & 0 & $\begin{array}{l}- \\
+\end{array}$ & $\begin{array}{l}1 \\
2 \\
1 \\
2\end{array}$ & $\begin{array}{l}1 \cdot 48 \\
1.41 \\
2 \cdot 87 \\
2 \cdot 82\end{array}$ & $\begin{array}{l}0.58 \\
0.37 \\
1 \cdot 08 \\
0.96\end{array}$ & $\begin{array}{l}\bar{z} \\
\overline{-} \\
-\end{array}$ & $\begin{array}{l}64 \\
98\end{array}$ & - \\
\hline 15 & $22 \cdot 5$ & $\begin{array}{l}- \\
+\end{array}$ & $\begin{array}{l}1 \\
2 \\
1 \\
2\end{array}$ & $\begin{array}{l}1 \cdot 62 \\
1.55 \\
2 \cdot 86 \\
2 \cdot 82\end{array}$ & $\begin{array}{l}0.58 \\
0 \cdot 13 \\
0.85 \\
0.33\end{array}$ & $\begin{array}{l}0.34 \\
0.28 \\
0.67 \\
0.55\end{array}$ & $\begin{array}{l}23 \\
39\end{array}$ & $\begin{array}{l}82 \\
82\end{array}$ \\
\hline 0 & 45 & $\begin{array}{l}- \\
+\end{array}$ & $\begin{array}{l}1 \\
2 \\
1 \\
2\end{array}$ & $\begin{array}{l}1 \cdot 18 \\
1.23 \\
2 \cdot 71 \\
2 \cdot 72\end{array}$ & $\begin{array}{l}- \\
- \\
-\end{array}$ & $\begin{array}{l}0.55 \\
0.41 \\
1.39 \\
1.09\end{array}$ & $\begin{array}{l}- \\
-\end{array}$ & $\begin{array}{l}77 \\
78\end{array}$ \\
\hline
\end{tabular}

Values are mean results for four ejaculates and are expressed as $\mu$ mole $/ 10^{8}$ spermatozoa over the experimental period $(3 \mathrm{hr})$. The ${ }^{14} \mathrm{CO}_{2}$ ratio is the ${ }^{14} \mathrm{CO}_{2}$ formed from $\left[2-{ }^{14} \mathrm{C}\right] l$ lactate or $\left[2-^{14} \mathrm{C}\right]-$ acetate expressed as a percentage of the ${ }^{14} \mathrm{CO}_{2}$ formed from $\left[1-{ }^{14} \mathrm{C}\right]$ lactate or $\left[1-{ }^{14} \mathrm{C}\right]$ acetate.

SUMMARY OF THE ANALYSES OF VARIANCE

\begin{tabular}{|c|c|c|c|c|c|}
\hline \multirow{3}{*}{ Source of variation } & \multicolumn{2}{|c|}{$\mathrm{O}_{2}$ uptake } & \multicolumn{3}{|c|}{$\mathrm{CO}_{2}$ formed } \\
\hline & \multirow{2}{*}{ d.f. } & \multirow{2}{*}{ Variance ratio } & \multirow{2}{*}{ d.f. } & \multicolumn{2}{|c|}{ Variance ratios } \\
\hline & & & & Lactate & Acetate \\
\hline A: Substrate differences & 2 & $5 \cdot 57^{* *}$ & 1 & $53 \cdot 30^{* *}$ & $65 \cdot 91^{* *}$ \\
\hline B: Addition of $\mathrm{K}^{+}+\mathrm{Mg}^{2+}$ & 1 & $473 \cdot 64^{* *}$ & 1 & $108 \cdot 02^{* *}$ & $115 \cdot 63^{* *}$ \\
\hline C: Carbon atom labelled & 1 & 0.21 & 1 & $74 \cdot 50^{* *}$ & $9 \cdot 79 * *$ \\
\hline $\begin{array}{l}\text { Interactions } \\
\mathbf{A} \times \mathbf{B} \\
\mathbf{A} \times \mathbf{C} \\
\text { Other }\end{array}$ & $\begin{array}{l}2 \\
2 \\
3\end{array}$ & $\begin{array}{l}1.38 \\
0 \cdot 18 \\
0.02\end{array}$ & $\begin{array}{l}1 \\
1 \\
2\end{array}$ & $\begin{array}{c}17.42^{* *} \\
18.55 * * \\
0.56\end{array}$ & $\begin{array}{c}21 \cdot 84 * * \\
1 \cdot 71 \\
0.83\end{array}$ \\
\hline Ejaculate differences & 3 & $89 \cdot 34^{* *}$ & 3 & $23 \cdot 09 * *$ & $13 \cdot 80^{* *}$ \\
\hline Ejaculate interactions (error) & 33 & 0.0486 & 21 & 0.0113 & 0.0187 \\
\hline
\end{tabular}

** $P<0.01$.

of $5 \mathrm{ml}$ volume and the washed aliquots were reconstituted in an appropriate volume of diluent to ensure that sperm numbers in the unwashed and washed samples were similar (mean $2 \cdot 2 \times 10^{8}$ cells/flask). Shortly before incubation small amounts of diluents containing appropriate quantities of fructose and/or lactate were added to the samples so that flasks containing $6 \mu$ mole fructose plus $4 \mu$ mole lactate were compared with flasks containing $6 \mu$ mole fructose

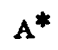


plus $12 \mu$ mole lactate. The semen at incubation had been diluted approximately 1:9. The results of four replicates (Table 3) show an interaction of the effects of washing and of storing at $37^{\circ} \mathrm{C}$ on the ratio of the amount of carbon dioxide formed from carbon atom two of lactate to the amount of carbon dioxide formed from carbon atom one. With fresh semen the ratio was lower after washing. Storage at $37^{\circ} \mathrm{C}$ resulted $(P<0.01)$ in greater decreases in the ${ }^{14} \mathrm{CO}_{2}$

TABLE 5

EFFECTS OF $\mathrm{KCl}$ ( $1 \mathrm{~mm}$ ) AND $\mathrm{MgCl}_{2}$ (2 mM) ON THE OXIDATION OF LACTATE BY WASHED RAM SPERMATOZOA

\begin{tabular}{|c|c|c|c|c|c|}
\hline Buffer & $K^{+}+M g^{2+}$ & $\begin{array}{l}\text { Position } \\
\text { of } \\
{ }^{14} \text { C label }\end{array}$ & 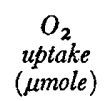 & $\begin{array}{c}\mathrm{CO}_{2} \text { formed from carbon } \\
\text { position labelled } \\
(\boldsymbol{\mu m o l e})\end{array}$ & $\begin{array}{c}{ }^{14} \mathrm{C} \text { accumulated } \\
\text { as acetate } \\
(m \mu \mathrm{c})\end{array}$ \\
\hline Phosphate & $\begin{array}{l}- \\
+\end{array}$ & $\begin{array}{l}1 \\
2 \\
1 \\
2\end{array}$ & $\begin{array}{l}1.79 \\
1 \cdot 77 \\
2 \cdot 79 \\
2.84\end{array}$ & $\begin{array}{l}0.62 \\
0.45 \\
0.76 \\
0.65\end{array}$ & $\begin{array}{l}8 \cdot 56 \\
7 \cdot 86\end{array}$ \\
\hline Tris & $\begin{array}{l}- \\
+\end{array}$ & $\begin{array}{l}1 \\
2 \\
1 \\
2\end{array}$ & $\begin{array}{l}2.42 \\
2 \cdot 35 \\
2.92 \\
2 \cdot 87\end{array}$ & $\begin{array}{l}0.87 \\
0.68 \\
0.90 \\
0.76\end{array}$ & $\begin{array}{r}11 \cdot 58 \\
7 \cdot 56\end{array}$ \\
\hline
\end{tabular}

Values are the means for four ejaculates expressed per $10^{8}$ spermatozoa over the experimental period (3 hr).

SUMMARY OF ANALYSES OF VARIANCE

\begin{tabular}{|c|c|c|c|c|c|c|}
\hline \multirow[b]{2}{*}{ Source of variation } & \multirow[b]{2}{*}{ d.f. } & \multicolumn{2}{|c|}{ Variance ratios } & \multirow[b]{2}{*}{ Source of variation } & \multirow[b]{2}{*}{ d.f. } & \multirow{2}{*}{$\begin{array}{c}\text { Variance } \\
\text { ratio } \\
\text { (Acetate } \\
\text { accumulated) }\end{array}$} \\
\hline & & $\begin{array}{c}\mathrm{O}_{2} \\
\text { uptake }\end{array}$ & $\begin{array}{c}\mathrm{CO}_{2} \\
\text { formed }\end{array}$ & & & \\
\hline $\begin{array}{l}\text { A: Difference between } \\
\text { buffers }\end{array}$ & 1 & $7 \cdot 35^{*}$ & $28 \cdot 22^{* *}$ & $\begin{array}{c}\text { A: Difference between } \\
\text { buffers }\end{array}$ & 1 & 0.73 \\
\hline $\begin{array}{l}\text { B: Addition of } \\
\qquad \mathrm{K}^{+}+\mathrm{Mg}^{2+}\end{array}$ & 1 & $38 \cdot 04^{* *}$ & $10 \cdot 37 * *$ & B: Addition of & & \\
\hline $\begin{array}{l}\text { G: Carbon position } \\
\text { labelled }\end{array}$ & 1 & 0.03 & $19 \cdot 31^{* *}$ & $\mathrm{~K}^{+}+\mathrm{Mg}^{2+}$ & 1 & $2 \cdot 21$ \\
\hline $\begin{array}{l}\text { Interactions } \\
\text { A } \times \text { B } \\
\text { Other }\end{array}$ & $\begin{array}{l}1 \\
3\end{array}$ & $\begin{array}{l}4 \cdot 42^{*} \\
0 \cdot 04\end{array}$ & $\begin{array}{l}2.69 \\
0.22\end{array}$ & $\begin{array}{l}\text { Interaction } \\
\quad \mathrm{A} \times \mathrm{B}\end{array}$ & 1 & $1 \cdot 11$ \\
\hline Ejaculate differences & 3 & $13 \cdot 80^{* *}$ & $21 \cdot 53^{* *}$ & Ejaculate differences & 3 & $1 \cdot 76$ \\
\hline $\begin{array}{l}\text { Ejaculate interactions } \\
\text { (error) }\end{array}$ & 21 & $0 \cdot 1253$ & 0.0099 & $\begin{array}{l}\text { Ejaculate interactions } \\
\text { (error) }\end{array}$ & 9 & $9 \cdot 985$ \\
\hline
\end{tabular}

ratio of unwashed spermatozoa (57\% decrease) than of washed spermatozoa $\left(30 \%\right.$ decrease) so that, after storage at $37^{\circ} \mathrm{C}$, the ${ }^{14} \mathrm{CO}_{2}$ ratio was higher for washed than for unwashed spermatozoa. Storage at $37^{\circ} \mathrm{G}$ greatly depressed oxygen uptake $(P<0.01)$. There were no effects of changing the concentration of substrate.

Aliquots of four ejaculates $\left(3.1\right.$ to $8.5 \times 10^{8}$ cells/flask) were incubated in double side-arm Warburg flasks (volume 15 to $30 \mathrm{ml}$ ) with diluents containing lactate $(30 \mu$ mole/flask $)$, lactate $(15 \mu$ mole/flask $)$ plus acetate $(22.5 \mu$ mole $/$ 
flask), or acetate alone ( $45 \mu$ mole/flask) either with or without the addition of potassium and magnesium. After temperature equilibration, $0.3-\mathrm{ml}$ aliquots of washed spermatozoal suspension were added from a side arm to $2.7 \mathrm{ml}$ of incubation diluent in the main compartment and incubated at $37^{\circ} \mathrm{C}$ for $3 \mathrm{hr}$. The results and statistical analysis are given in Table 4.

The effects of the inclusion of potassium $(1 \mathrm{~mm})$ and magnesium $(2 \mathrm{~mm})$ chlorides in the diluent on the metabolism of lactate by washed ram spermatozoa were studied further. Using the basic diluent containing sodium lactate $(6 \mathrm{~mm})$ and a diluent containing trishydroxymethylaminomethane- $\mathrm{HCl}$ (tris) buffer $(20 \mathrm{~mm})$, sodium chloride $(128 \mathrm{~mm})$, and sodium lactate $(6 \mathrm{~mm})$, spermatozoa were incubated at $37^{\circ} \mathrm{C}$ for $3 \mathrm{hr}$ in small Warburg flasks with and without the addition of potassium plus magnesium. After incubation, metabolism was terminated by adding $0.8 \mathrm{ml}$ of the flask contents to $3.6 \mathrm{ml}$ of ethanol containing $0.1 \mathrm{ml}$ of $2 \mathrm{~N} \mathrm{NaOH}$ which was placed in a water bath $\left(70^{\circ} \mathrm{C}\right)$ for $5 \mathrm{~min}$. After centrifuging, the carboxylic acids present in the supernatant were separated by silicic acid chromatography. The $\left[1-{ }^{14} \mathrm{C}\right]$ lactate and $\left[2-{ }^{14} \mathrm{C}\right]-$ lactate were purified by silicic acid chromatography before use and aliquots, incubated in the absence of semen, were used as controls in the silicic acid chromatograms. The mean results for four ejaculates $\left(2.0\right.$ to $4.2 \times 10^{8}$ cells/flask $)$ are shown in Table 5. Accumulation of acetate and decrease in lactate were the only changes observed in the silicic acid chromatograms. Accumulation of acetate was not observed using $\left[1-{ }^{14} \mathrm{C}\right]$ lactate and the treatments had no significant effect on the accumulation of labelled acetate from $\left[2-{ }^{14} \mathrm{C}\right]$ lactate.

\section{DISCUSSION}

The present experiments show that a number of treatments can influence the relative production of carbon dioxide from carbons one and two of lactate. In general, unfavourable environmental influences decrease the oxidation of carbon two of lactate compared with that of carbon one, and this alteration in lactate metabolism would appear to correspond to the degree of cell damage. Thus, increasing the rate at which the cells are cooled to $5^{\circ} \mathrm{C}$ decreases the ratio of carbon dioxide formed from carbon two to that formed from carbon one and this change closely parallels the effects of cooling on the percentage of spermatozoa stained by supravital dyes. Ageing of the cells by incubation at $37^{\circ} \mathrm{C}$ for $3 \mathrm{hr}$ also decreases the above ratio. In buffered suspensions of spermatozoa the accumulation of lactate during cooling and storage would not be expected to change the $\mathrm{pH}$ sufficiently to cause the alteration in metabolism of lactate noted in previous reports (O'Shea \& Wales, 1966, 1967).

The present experiments indicate that decreases in the ratio:

$$
\frac{{ }^{14} \mathrm{CO}_{2} \text { from }\left[2-{ }^{14} \mathrm{C}\right] \text { lactate }}{{ }^{14} \mathrm{CO}_{2} \text { from }\left[1-^{14} \mathrm{C}\right] \text { lactate }}
$$

are related to changes in the incubation diluent as well as to changes in the cell itself. Hence, removal of seminal plasma and replacement by buffered saline decreases the ratio. This is probably due to the removal of potassium and magnesium ions as their addition to washed suspensions returned the ratio almost to 
unity. Thus, the use of $\left[1-{ }^{14} \mathrm{C}\right]$ lactate probably over-estimates lactate oxidation by suspensions of washed spermatozoa where $\mathrm{K}^{+}$and $\mathrm{Mg}^{2+}$ are not added. With unwashed suspensions, the ratio is near unity and the use of $\left[1-{ }^{14} \mathrm{C}\right]$ lactate does not bias the estimates.

Another important environmental influence on the ratio is the presence in the medium of alternate substrates which, with lactate, form a metabolic pool for entry into the citric acid cycle. The substitution of acetate for some of the lactate in the incubation diluent greatly suppresses the oxidation of carbon two of lactate. The present experiments have shown that acetate can accumulate during incubation with lactate as substrate and such an accumulation probably accounts for some of the decrease in the ratio that occurs when diluted semen is kept at $37^{\circ} \mathrm{C}$ for $3 \mathrm{hr}$ before oxidation is measured. This is not the only cause of the alteration in lactate metabolism under these conditions as cells kept at $37^{\circ} \mathrm{C}$ for $3 \mathrm{hr}$ and washed before incubation still show a decreased capacity to oxidize carbon two of lactate.

Since spermatozoa oxidize lactate and acetate to carbon dioxide through the Krebs' tricarboxylic acid cycle (Salisbury \& Lodge, 1962; Scott, White \& Annison, 1962; Flipse, 1964; Mohri, Mohri \& Ernster, 1965), the accumulation of labelled acetate from $\left[2-{ }^{14} \mathrm{C}\right]$ lactate and not from $\left[1-{ }^{14} \mathrm{C}\right]$ lactate is explicable. Because of the increased rate of entry of acetate into the citric acid cycle and the effect on the citric acid cycle caused by potassium and magnesium (Beinert, Green, Hele, Hift, Von Korff \& Ramakrishnan, 1953; Von Korff, 1953; Krebs \& Lowenstein, 1960), it was anticipated that there would be less acetate accumulated when these ions were added. Although this did not occur, inspection of the data reveals that this effect occurred in the two more dilute ejaculates but not in the two more dense ejaculates. Thus, a low sperm density may be necessary to show this effect consistently.

According to Krebs \& Lowenstein (1960), the intermediates of the tricarboxylic acid cycle do not normally accumulate to appreciable levels in respiring cells. This would appear to be the case for spermatozoa as only acetate accumulation was observed on chromatography.

\section{ACKNOWLEDGMENTS}

The authors are indebted to Professor C. W. Emmens for interest and criticism and to Dr R. A. Leng for bringing to our notice the advantages of hexane : butanol solvents. The work was aided by grants from the Rural Credits Development Fund of the Commonwealth Bank of Australia, and the Australian Wool Board.

\section{REFERENCES}

Beinert, H., Green, D. E., Hele, P., Hift, H., von KorfF, R. W. \& Ramakrishnan, C. V. (1953) The acetate activating enzyme system of heart muscle. . biol. Chem. 203, 35.

Blackshaw, A. W. (1953) The effects of potassium and calcium salts on the motility of ram, rabbit and bull spermatozoa. 7. Physiol., Lond. 120, 465.

Blackshaw, A. W. (1958) The effects of glycerol on the supravital staining of spermatozoa. Aust. vet. $\mathcal{F}$. 34, 71 .

Bulen, W. A., Varner, J. E. \& Burrell, R. C. (1952) Chromatographic technique. Separation of organic acids from plant tissues. Analyt. Chem. 24, 187. 
Donaldson, K. O., Tulane, V. J. \& Marshali, L. M. (1952) Automatically increasing solvent polarity in chromatography. Analyt. Chem. 24, 185.

DotT, H. M. \& WhITE, I. G. (1964) Effect of potassium on ram spermatozoa studied by a flow dialysis technique. F. Reprod. Fert. 7, 127.

Emmens, C. W. (1947) The motility and viability of rabbit spermatozoa at different hydrogen ion concentrations. F. Physiol., Lond. 106, 471.

Furpse, R. J. (1964) Products of acetate metabolism by bovine spermatozoa. 5th int. Congr. Anim. Reprod., Trento, Vol. III, p. 334.

Krebs, H. A. \& Lowenstein, J. M. (1960) The tricarboxylic acid cycle. In: Metabolic Pathways, Vol. I, p. 129. Ed. D. M. Greenberg. Academic Press, New York.

LARdy, H. A. \& Phillips, P. H. (1943) Effect of $\mathrm{pH}$ and certain electrolytes on the metabolism of ejaculated spermatozoa. Am. F. Physiol. 138, 741.

Mohri, H., MohrI, T. \& ERnster, L. (1965) Isolation and enzymic properties of the midpiece of bull spermatozoa. Expl Cell Res. 38, 217.

Nersh, A. C. (1949) Production and properties of 2:3 butanediol. XXX. Determination of the fermenta tion acids by partition chromatography. Can. F. Res. B, 27, 6 .

O'SHEA, T. \& WALES, R. G. (1964) Effects of potassium on ram spermatozoa during chilling to and storage at $5^{\circ}$ C. J. Reprod. Fert. 8, 121.

O'Shea, T. \& Wales, R. G. (1966) Effect of casein, lecithin, glycerol and storage at $5^{\circ} \mathrm{C}$ on diluted ram and bull semen. Aust. F. biol. Sci. 19, 871 .

O'SheA, T. \& Wales, R. G. (1967) The metabolism of ram, bull, dog and rabbit spermatozoa after cooling to $5^{\circ}$ C. Aust. F. biol. Sci. 20, 447.

SAlisburx, G. W. \& Lodge, J. R. (1962) Metabolism of spermatozoa. Adv. Enzymol. 24, 35.

Scorr, T. W., White, I. G. \& AnNison, E. F. (1962) Oxidation of short-chain fatty acids $\left(\mathrm{C}_{1}-\mathrm{C}_{8}\right)$ by ram, bull, dog and fowl spermatozoa. Biochem. F. 83, 392.

Von Korpr, R. W. (1953) The effects of alkali metal ions on the acetate activating enzyme system. 7. biol. Chem. 203, 265.

Wales, R. G. \& O'SheA, T. (1966) The oxidative utilization of fructose and acetate by washed ram spermatozoa in the presence or absence of potassium and magnesium. Aust. F. biol. Sci. 19, 167.

WALLACE, J. G. \& WALEs, R. G. (1964) Effect of ions on the metabolism of ejaculated and epididymal ram spermatozoa. F. Reprod. Fert. 8, 187.

Whitr, I. G. (1953a) Metabolic studies of washed and diluted ram and bull spermatozoa. Aust. $\mathcal{J}$. biol. Sci. 6, 706.

Whrte, I. G. (1953b) The effect of potassium on the washing and dilution of mammalian spermatozoa. Aust. F. exp. Biol. med. Sci. 31, 193. 